\title{
Why withdrawal from the European Union is undemocratic
}

\author{
TORE VINCENTS OLSEN and CHRISTIAN F. ROSTBØLL \\ Department of Political Science, Aarhus University, Denmark and Department of Political Science, \\ University of Copenhagen, Denmark
}

E-mail: tvo@ps.au.dk

\begin{abstract}
The Lisbon Treaty from 2009 introduced the possibility for individual member states to withdraw from the European Union (EU) on the basis of a unilateral decision. In June 2016 the United Kingdom decided to leave the EU invoking article 50 of the treaty. But is withdrawal democratically legitimate? In fact, the all-affected principle suggests that it is undemocratic for subunits to leave larger political units when it adversely affects other citizens without including them in the decision. However, it is unclear what the currency of this affectedness is and, hence, why withdrawal would be undemocratic. We argue that it is the effect of withdrawal on the status of citizens as free and equal that is decisive and that explains why unilateral withdrawal of subunits from larger units is democratically illegitimate. Moreover, on the 'all-affected status principle' that we develop, even multilaterally agreed withdrawal is undemocratic because the latter diminishes the future ability of citizens to make decisions together regarding issues that affect their status as free and equal. On this basis, we conclude that it is undemocratic for a member state such as the United Kingdom to withdraw from the EU.
\end{abstract}

Keywords: democracy; all-affected principle; citizen status; boundary problem; European Union; withdrawal clause

The British decision to leave the European Union (EU) in the referendum held on the 23 June 2016 was made possible by article 50 in the Lisbon Treaty which allows member states to the leave the EU on their own decision. Before the Lisbon Treaty EU membership was in principle for eternity. The Brexit decision has been criticized for being based on a democratic process of poor quality due to manipulation of facts and unrealistic promises for the future. But few have questioned the democratic legitimacy of the British people unilaterally deciding on whether or not to remain in the EU. In this article, as part of a general argument, we will do exactly that. We argue that withdrawal from the EU by any member state cannot be defended from the perspective of fundamental democratic principles. Withdrawal violates basic democratic commitments and undermines the possible democraticness of relationships 
that should be democratic. The main reason for this assessment is that EU citizens across borders mutually affect each other's fundamental interests and that the EU affords citizens with a status of individual rights holders and co-rulers that would be seriously affected by unilateral withdrawal by one state. The problem is twofold. First, all those whose status is affected by the decision to withdraw are not included in making it. Second, by withdrawing from the EU, citizens will be less able to rule together democratically with regard to the issues that affect them and their status across borders. While some degree of national self-determination is called for by democratic principles, national self-determination cannot be absolute; that is, it cannot trump the democratic right (of other citizens) to participate in decisions that significantly affect them as individuals and as citizens; a right which is (otherwise) institutionalized by the EU. We therefore conclude that unilateral and even mutually agreed withdrawal from the EU cannot be defended on the basis of democratic principles as easily as some believe.

We build our case against withdrawal from the EU on a development of the all-affected principle, which says that all those affected by a decision should be included in making it. In the literature, there has been a discussion about what is the relevant understanding of being affected; what the currency of affectedness is. A central notion is that it is the affectedness of individual interests, either actually or potentially, that explains why and when people should be included in decisions. This results in the all-affected interests principle. Another idea is that it is not the fact that one's interests are affected that is decisive for whether one should be included in decisions or not but that one is subjected to potential coercion. This results in the allsubjected principle. Building on the criticism of these two principles and taking inspiration from the literature on non-domination, we develop our own conception of the currency of affectedness and formulate the all-affected status principle, which states that persons whose status as free and equal is mutually dependent should be ensured democratic equality through inclusion in common political institutions. ${ }^{1}$

The discussion of EU and democracy has often been based on disputes about which model of democracy to apply to the EU. Judgements about EU democracy are made dependent on which model of democracy you subscribe to, for example, whether you are committed to a realist or an idealist model of democracy, and on whether you think that the member state is the primary locus of democracy in the EU or you hold faith in a federal EU democracy. Of course, few people are completely satisfied with

1 This does not exclude the possibility of different levels of government, but all those whose status is affected by one another should be able to participate equally in the political institutions that determine their overall status. 
discussing EU democracy in this manner because the choice between models seems arbitrary. To avoid this, efforts are made to outline minimal and typically realist accounts of democracy that can serve as a common ground for deciding between models (e.g. Moravcsik 2002; Føllesdal and Hix 2006). The trouble with this approach is that it is tied to convention and fails to provide a critical standard for evaluating current democratic affairs.

But the general idea is sound: common ground is needed to decide between models. And the common ground must be based on 'the point of democracy'. While this point is contested, there is a common core of principles that cannot be denied without leaving the democratic terrain (cf. Connolly 1993). We base our argument on the all-affected principle. We contend that it is hard to deny that this is a key democratic principle. Models of (EU) democracy must show that they can live up to this principle in one way or another. Taking this starting point also means that our argument is at a higher level of abstraction than the usual 'models of EU democracy approach' while at the same time giving us some leverage to criticize specific models, especially those which would have no democratic objections to member states leaving the EU.

So while some might think that the all-affected principle is tied a specific model of democracy, for example, a national model of democracy, the argument goes the other way round: all models of democracy must be tied to the principle to be models of democracy. Conversely, some might think that the all-affected principle is per se a cosmopolitan principle. However, this is also not true. We will develop the principle in a manner that takes other democratic intuitions into account so that it does not necessarily imply global political institutions, but only have such implications under certain conditions. Also, some might fear that our approach ignores the democratic benefits and values tied to established democratic institutions and to stable and bounded political communities, and not least to national self-determination. However, we will show that in the context of the EU it is possible to accommodate these values and benefits. Extensive national self-determination does not conflict with the all-affected principle, as we develop it; only sovereign or absolute national self-determination does so.

Finally, our argument is limited to the point that withdrawal cannot be defended on democratic grounds. It does not address whether other principles than democratic ones can account for the political legitimacy of international or supranational organizations such as the EU (Buchanan and Keohane 2006). Our claim is that it is undemocratic to leave the EU, not that it is illegitimate all things considered to do so. To make the latter claim would require more work than we are able to do here. Our argument is conditional on the acceptance of democratic principles being relevant in the present case. 
The structure of the paper is as follows. First, we briefly explain the case regarding the right to withdrawal from the EU. Then, we discuss the fundamental nature of democracy and advance the argument that democratic principles can say something about how to constitute the demos. In this connection, we propose a version of the all-affected principle that focusses on a republican notion of status. This is followed by a response to nationalist and statist arguments against expanding the demos. Having these theoretical arguments in place, we turn to an application of our all-affected status principle to the case at hand, arguing that withdrawal from the EU is detrimental to the democratic status of current EU citizens. Finally, we consider some EU-specific objections to our argument, for instance, regarding the democratic deficit of the EU and the idea that the EU should be seen as a demoi-cracy, in which a unilateral right to withdraw is inherent.

\section{The right to withdraw and European citizenship}

According to article 50(1) in the revised Treaty on the European Union (TEU), 'Any member state may decide to withdraw from the EU in accordance with its own constitutional provisions' (EU 2010). The withdrawing member state should notify the European Council of its decision, and after obtaining the consent of the European Parliament, the Council of Ministers, acting on the basis of a qualified majority, should conclude an agreement with the withdrawing state on 'the arrangements of withdrawal' and 'the framework of its future relationship with the Union' (EU 2010, TEU article 50(2)). These formulations suggest that withdrawal would be based on multilateral agreements, but this is not the case. If no agreement between the withdrawing state and the remaining Union is reached, the treaties will 'cease to apply' 'two years after the notification'. It is hence an unconditional unilateral right to withdraw, only limited by the 2-year-waiting period. The rationale of the clause is that the member states remain the 'masters of the treaties' (Hofmeister 2010, 592). It underlines the equality and sovereignty of states and the right to national self-determination. As the Lisbon Treaty moves the EU ever closer to (qualified) majority voting, the previously dominant principle of unanimity and national veto is replaced by a right to exit (Holberg 2010, 16).

Through its fundamental principles, freedoms, rights, and the concept of EU citizenship, the EU supplies individuals with rights across borders, both as legal subjects and as citizens (cf. EU 2010, TEU article 2, 9-12). While originally tied to the creation of the internal market and an integrated European economy, rights are now seen as protecting important individual interests (De Burca 2011). Similarly, institutional reforms to enhance the 
powers of the European Parliament, to include the national parliaments in the EU legislative procedure as well as the introduction of the citizens' initiative point to a conception of 'active citizenship' in the EU that is not sufficiently realized by long chains of formal political representation alone. As legal subjects or private individuals, EU citizens are able to move to another EU country to work, study, retire, buy property, make contracts, and receive and supply services and goods as they see fit, bringing their family with them (or creating a new one). Abroad, they have to be treated as local national citizens with regard to almost all institutions and public goods and services, and they are entitled to vote in local and European elections. Staying home, EU citizens can, as private individuals, avail themselves of goods and services (private and some public) supplied in other EU countries, and buy property and make contracts there, and so on. Through national and European institutions, they can, as citizens, exercise political influence on political matters that affect them in a significant manner. The right to withdraw from the EU must be seen against this double status of EU citizens; the double status of having rights across borders not only as a subject to law but also as the source of law. This double status implies that one's status as a rights bearer cannot be changed without one being able democratically to take part in the decisionmaking process in which this status is changed. In principle, the EU respects each EU citizen's 'status as a ruler' across borders (cf. Brettschneider 2007, 3, 19). To be precise, our concern is not just the nominal status of being an EU citizen, but the material content in terms of which relations you are standing in with whom. The fact that one country's citizens could nominally remain EU citizens and in sense keep an unchanged status even after all other countries have left the EU is not what we discuss here.

The exact interpretation of the legitimacy basis of the EU is likely to always be disputed (Olsen 2011), and the EU is the result of a compromise between different views of what the EU is and should become. Nonetheless, there is a tension built into the way that the EU is constituted between the EU citizens as rights holders and co-rulers across borders and the right to withdraw since the latter removes 'the rights of others' (Benhabib 2004) without giving those others a say in the matter. We argue that this tension should be resolved to the benefit of the EU citizens as co-rulers and rights holders and that this could be done without undermining the value of national identity and self-determination.

\section{Democratic principles, democratic procedures, and constituting the demos}

Our question is whether a member state's unilaterally withdrawing from the EU can be defended with democratic reasons. Democratic reasons will refer to democratic institutions, democratic criteria, or democratic 
principles rather than extra-democratic reasons of, for instance, efficiency or justice. Obviously, everything hinges on what counts as a (good) democratic reason, and the following discussion is aimed at clarifying that question.

To begin with, it is not sufficient for a decision to be democratic that it is made through democratic procedures, for instance, by representatives elected in free and fair elections or by a referendum, since such a decision is not immune from criticism based on democratic reasons. First, if a decision undermines the preconditions for making democratic decisions in the future, for instance, a decision to disenfranchise a large portion of the population, it cannot be called democratic. There are good democratic reasons for criticizing such a decision. Second, we must ask who were entitled to participate in the political process that produced the decision. A decision made following a democratic method would still fail on democratic terms if only a small part of the population were entitled to participate, as in South Africa under Apartheid (Dahl 1989, 121-22). Our reasons for objecting to calling a decision democratic only because of the method used are respectively forward-looking and backward-looking. The first looks to the consequences for democracy in the future. The second looks backward to a democratic criterion of inclusion.

The boundary problem of who should belong to 'the people' that is to rule themselves has been taken for granted and largely ignored in the history of democratic theory (Dahl 1990, 45ff). Some theorists have claimed that democratic theory can say something only about procedures and little, if anything, about boundaries and that the determination of boundaries must therefore be left to history and force (Schumpeter 1975, 243-45; Whelan 1983, 40; Saunders 2011). But that is hardly satisfactory when - as in the present case - we have a conflict between different possible demoi as the right one to make a decision. While it is true that the initial constitution of the demos cannot happen using a democratic procedure because we do not know who should be included in the vote, this position relies on an understanding of democracy that fails to distinguish between fundamental democratic principles and the institutions or decision-making methods that are thought to instantiate these principles (Arrhenius 2012).

Note, also, that if democratic theory can say nothing about the constitution of the demos, then democratic theory cannot say anything about whether unilateral or mutually agreed withdrawal between citizens of all member states of the EU is most democratic. As long as a democratic decision-making method is used, the result must be accepted as democratic. This means that democratic theory cannot assess one composition of the demos over another, say, a national member state based one over one based on all EU citizens - and thereby that citizens of a withdrawing state cannot 
complain on democratic grounds if their decision to do so was overruled by members of a European demos.

The debate initiated by proponents of some version of the 'all-affected principle', which says that all those affected by a decision should be included in it, is helpful here. Considering the democratic reasons that can be given for delimiting the demos, we begin with the all-affected principle and develop it against the criticisms that have been levelled against it for not taking the nature of democratic rule itself sufficiently into account. We then turn to the second set of criticisms of the principle, which are mainly based on the qualities of nations and/or states as the basic units for democratic rule. We address these criticisms either by showing that more weight ought to be given to the rights of others affected or that institutionalizing our version of the all-affected principle does not - in a reasonably realistic interpretation of it - undermine the democratic qualities that critics think it does.

\section{Identity of rulers and ruled}

Our democratic intuitions imply that there ought to be some kind of identity between rulers and ruled. It does not seem democratic for demos A to make decisions for demos B that does not apply to A itself, even if A followed a democratic procedure. More interesting is the case in which A makes decisions for itself, which also subjects or affects other people. This means that even if demos $\mathrm{A}$ is only intent on ruling itself, these other people may still complain that complete identity does not exist between rulers and ruled since they are affected but have been left out of the decision making.

Contemporary literature distinguishes between two different principles that help to specify what it means to be ruled. The first is the all-subjected principle, which says that all those subjected to a rule should have an equal say in its formulation. Usually, being subjected means being subject to coercive force, as one is to a state's laws. The second is the all-affected principle, which says that all those who are (relevantly) affected by a decision should have an equal say in its formulation. There are different versions of the all-affected principle, depending on how 'relevantly affected' is specified. Most commonly, the all-affected principle is understood as an all-affected interests principle, saying that it is the effect on your interests that triggers the right to participate (Dahl 1990; Goodin 2007; Arrhenius 2012, 49). From the domestic point of view, the all-subjected and the all-affected principles are often used in order to argue for an extension of who has a right to participate to 'outsiders' (Goodin 2007; Abizadeh 2008), although not always, since it may exclude long-term expatriates from participation in their countries of origin (López-Guerra 2005). 
'Perhaps the most common justification given for democracy is that it is essential to the protection of the general interests of the persons who are subject to the regulations or actions of the officials of the state' (Dahl 1989, 93). Mill argued that 'the rights and interests of every or any person are only secure from being disregarded, when the person interested is himself able, and habitually disposed, to stand up for them' $(1991,245)$ and, therefore, that each person should have a right to vote in democratic elections. Note that if democracy is justified by its protection of interests, then it simultaneously justifies an all-subjected or an all-affected principle. If my right to vote is necessary for the protection of my interests, then I should have the right to vote in any decision process that (subject me to a rule that) affects my interests. If democracy is about protecting interests, there must be identity between those whose interests need protecting and those who can participate.

This also means that it is unclear why we should accept the all-subjected principle rather than the more expansive all-affected principle. If interests are what matter and not only the fact that one is part of an already constituted demos and subject to an already existing state (as presumed in the quote from Dahl above), then why not be concerned with the people who are nonetheless affected by the decisions of that state? Note also an important difference between the two principles. The all-subjected principle 'takes the existence of a political unit for granted. It assumes the state as a primary boundary or threshold for inclusion and exclusion and then argues that all those subjected to political rule within its boundaries ought to have a say in its making' (Näsström 2011, 117). The all-affected principle, by contrast, does not take the political unit for given but can be employed to determine which political units are most appropriate to establish to give people the opportunity to protect their interests.

\section{Democracy is not just interest protection}

It might be questioned, however, if the best way of understanding the ground of democracy is in terms of protecting interests since it appears to reduce persons to 'moral patients'. Democracy is rather about respecting persons as 'agents' capable of deliberation and reasoned choice: 'Democracy is essentially a matter of rule by the people. That is, a matter of their agency' (Saunders 2011, 287).

Indeed, the use of 'interests' is often unclear in the discussion of the allaffected interests principle. As mentioned above, from the domestic point of view, it appears to be an inclusive principle. However, from the global point of view, it is often seen as, and at times criticized for, being an exclusionary principle leaving out all those who might not be directly affected by any 
given decision or policy (T. McDonald 2012). The presumption often is that it is individual interests of various degrees of importance that are affected. Held (2010, 304-05) talks about 'needs or interests' at three different levels of importance: (a) those that regard individuals' physical existence, (b) their ability to participate in political and social contexts, and (c) their life-style choices. According to Held, affectedness on physical existence and the ability to participate carries more weight for inclusion into the decision making than affectedness in relation to life-style choices.

While Held's hierarchy of needs and interest may include interests of a more other-regarding nature (i.e. with regard to political participation), Gould (2004, Ch. 9, 2012) explicitly brings a collective dimension to her differentiation between issues that affect people's negative freedom based on a threshold defined by human rights and issues that affect the joint activities or common projects that people consciously pursue together as a precondition for and expression of their positive freedom. According to Gould, the former ought to trigger a right to influence decisions indirectly by providing input through, for instance, consultation of NGOs, while the latter require that people are given participatory rights. Gould thereby differentiates between different types of affectedness and the ensuing of rights to be included (right to influence vs. right to participate). Basing her democratic theory and the differentiation between the two different kinds of 'input' rights on equal positive freedom or 'equal agency', she follows authors such as Saunders in the emphasis on 'agency' and centrality of participation in determining common activities (Gould 2004, 176). In contrast to Saunders, however, she does not think that common activities or projects are limited to national boundaries and mentions the EU as an instance of a common project that reaches beyond national boundaries (Gould 2012). Still, even in pointing out the centrality of co-determining 'joint activities' and providing more guidance as to what it means to be relevantly affected, it is not clear that she moves beyond an individualistic or self-regarding perspective. Therefore, as other champions of the allaffected interests principle, she fails to address a central expectation associated with citizenship, namely, the orientation towards and participation in the determination of the public good.

Marchetti $(2012,33,38)$ touches upon this issue in his criticism of the allaffected principle. He thinks it is unable to take into account the impartial view of citizens deliberating about 'political justice' and is concerned that it excludes people who are not directly affected by decisions from participating in the determination of public values. This leads him to propose an all-inclusiveness principle as the basis for a global demos underpinning a vision of cosmo-federalism. 
The other-regarding perspective, taking the interests of others into account, shows an important intuition about democratic citizenship that the individualist conception of the all-affected principle neglects. However, it also raises difficult issues regarding 'which public's values' (or whose interests) one should be concerned about and entitled to participate in the determination of. This applies in particular if this other-regarding perspective is conceived as a moral perspective rather than as pertaining to the public values of a bounded ethical community. A moral perspective does not readily yield separate jurisdictions.

\section{The all-affected status principle}

Grounding democracy in protection of individual interests involves too strong a focus on the output of political decision making at the cost of a concern for input, agency, and participation in the determination of public affairs. Nonetheless, we run into absurdities if we say that democracy is only about providing opportunities for agency, and we need to supplement the moral perspective, which yields no boundaries, with a guiding principle for structuring the boundaries of the demos. Democracy is not only about acting; it is about acting on ourselves. It is a matter of people jointly acting for their own shared purposes.

The best way to think about this, we suggest, is to see democracy as, fundamentally, being about securing persons' political standing or status in relation to each other. In this view, democracy is justified because it constitutes a relationship among persons in which their political status as free and equal is respected. This status is not merely one of being equally free as subject to the laws but a status of being equally free as participants in making the laws that determine one's status. This notion connects to the fact that the EU treaties give citizens a double status of rulers and rights bearers across borders, even if that status is in tension with the notion of the member states as masters of the treaties and the right to withdraw.

We will refer to the fundamental principle of democracy as the principle of affected status. It says that people whose status as free and equal is mutually dependent ought to be included and remain in common democratic decision-making. Status, in this interpretation, is not something one can possess or understand independently of one's relations to other persons but, rather, a relation in which one stands to other persons. We speak of the specific status of being free and equal, by which we mean a form of reciprocal relationship in which no one can decide for others or bind others in ways that do not equally bind themselves (Rostbøll 2016). Persons are mutually dependent for their status as free and equal, when they cannot avoid standing in relationships that are either egalitarian or non-egalitarian, non-dominating 
or dominating. Thus, the principle applies among persons that have interactions that affect their status as free and equal. It says that when we have such interactions, we ought to join or remain in common democratic decisionmaking. If we do not join together democratically, we will be related in ways that does not respect our reciprocal standing as free and equal persons. Note, the status principle does not encompass all the positions we occupy in relation to others, but only the relationships that affect our fundamental standing as free and equal persons.

Because the status principle appeals to a relational understanding of people's status, it escapes the self-regarding aspect of the all-affected interests principle. It provides a moral basis of democracy as a matter of realizing an ideal of relating persons to each other in a way that respects their status as free and equal in relation to their ability to protect and further their private interests and their perception of the public interest. This moral basis of democracy can explain not only why we ought to make collective decisions following democratic procedures; it can also inform how to constitute the demos that makes democratic decisions. Democratic procedures respect the involved persons as free and equal insofar as they include them in collective decision-making, where each participates as an equal in giving laws to these same persons. The ideal of securing the status of being free and equal cannot ignore who is included in the decision making. If some persons can only have their status protected by being included in the decision making because they are dependent for their status on others included in the decision making, they ought also to be included.

The status principle might seem equivalent to the all-subjected principle insofar as they both say that anyone whose status is affected by a decision should be included in making that decision. But in contrast to the all-subjected principle, our status principle does not take the political unit for given. The status principle can say something both about who should participate in the decision making of the political units we already have and provide guidance regarding which political units we ought to have (or ought to establish). The status we speak of is not merely the positive legal status of a person but an ideal of how persons ought to stand in relation to each other. This ideal is one that calls for positive law and democratic institutions, but it is not irrelevant to this ideal how the borders between the political-juridical units are drawn. The principle requires that one shares political institutions with those to whom one is vulnerable in terms of one's status. Thus, the point is not merely to have a certain legal and political status, but to enjoy the status as free and equal in relation to persons with whom one interacts in ways that conditions one's fundamental status.

Kant (1996a, 451) argued that people who live 'side by side' should establish a common legal order to ensure the status and external freedom of 
all. He thought that everyone would eventually consider themselves part of a universal community and therefore ought to establish a cosmopolitan law to ensure each other's freedom (Bohman 2007, 23-24). The problem with this approach is that it is not very helpful in relation to dealing with the boundary problem unless we are satisfied with a world state of sorts. An alternative is to look at interdependence. Interdependence entails that actions and events taking place far away may have a very immediate impact on our lives here and now. But how does this affect status? We here take inspiration from the republican literature on domination and non-domination (Pettit 1997, 2010). You are dominated when others have the capacity to exert alien control over you and to interfere in your possible choices arbitrarily, that is, in a manner that does not track your interest in making certain choices, including acting on your perception of the public interest (e.g. proposing or criticizing specific policies). The relation between dominator and dominated is basically one of inequality; it involves an unequal status between the agents.

According to Pettit $(1997,2010)$, for domination to take place the dominating agent must have an intention to control the dominated party and the relation of domination should be common knowledge for all involved parties. This seems right since not all social and natural 'events' that interfere randomly with one's choice possibilities could be counted as domination (e.g. tsunamis and financial breakdowns). In light of the interdependency that globalization brings with it, this raises some issues regarding how to deal with unintended consequences of decisions and actions, that is, in regard to actions and decisions that randomly interfere with one's choices. Global competition driving whole industries and their workers out of business cannot be considered domination without further qualification. But threats of 'price dumping' as a means to control others' actions can. Bohman has argued that globalization brings with it asymmetrical relations that entail that specifiable but indefinite groups of people are involuntarily included into and often differentially affected by global structures of interdependence. This amounts to a form of domination (Bohman 2007, 25-26). While the intention and common knowledge dimension becomes less prominent in this conception of domination, it paves the way for the realization among involved parties that they are interfering/being interfered with arbitrarily. The potentially emerging consciousness of being tied together in this manner enables people at both ends of the relation to realize that their relation is one of domination in which their status is vulnerable to each other.

According to Bohman $(2007,45 \mathrm{ff})$, what is required for citizens to avoid domination in a globalized context is a 'democratic minimum' that gives citizens enough powers to initiate changes in their democratic rights so as to 
counteract domination and further justice. Bohman insists that his theory is institutional but it is vague as to which institutions would be needed to equip citizens with the required reflexive democratic powers (Forst 2007). However, the conception of non-domination is helpful in elucidating how the status of people as equally free can become vulnerable to each other and how this may occur across established jurisdictions and vary in degree. Its advantage is that it can show that status is not conceptually tied to already existing jurisdictions and institutions and that the all-affected status principle, when based on a notion of non-domination, can be used to determine what the proper units for democratic governance are. The all-affected status principle does not, as the all-subjected principle, rely on already established political units.

The question remains, however, what the relation is between nondomination and democratic equality. Pettit (1997, Ch. 4) offers an instrumental argument for democratic equality since such equality is most likely to be the best means to realize the highest level of overall non-domination. By contrast, Bohman (2007, Ch. 3) sees equal democratic rights as intrinsic to realizing non-domination. Thus, the democratic minimum should be conceived as a right to a membership status of a political community that allows citizens to make claims and initiate deliberation with other citizens who possess the same status in order to ensure each other against domination (Bohman 2007, 107). From this, and coming back to the notion of common knowledge as an aspect of domination/non-domination, we argue that equality of status is essential for realizing non-domination overall because the knowledge of unequal status would inherently entail domination. The domination would result from the knowledge that others are equipped with powers that might well trump your own (Pettit 1997, 113). Equality of status is hence inherent to non-domination. This means that the resolution to issues of domination that result from interdependence is to ensure a status of equal democratic membership. Thus, persons who can only be secure in their status as free and equal, as both subjects and makers of law, if they share political institutions, ought to share political institutions.

The all-affected status principle might seem a rather indeterminate principle. However, indeterminacy is not the same as emptiness, and our principle does provide quite clear guidance in some cases. We believe that the case of withdrawal from the EU is such a case because it is clear that current EU citizens are vulnerable in terms of their status in the material sense discussed above to other EU citizens and their governments.

So how, more specifically, can the principle of affected status inform our discussion of who should be included in which decision-making processes? As we have mentioned, there is both a backward-looking and a forward-looking 
version of this question. The backward-looking question assumes that the political unit is given and asks who should be included in the decision making of this unit. The answer based on the status view of equal freedom is that this status is respected only if one can participate in making the rules that determine one's fundamental status; otherwise, one does not stand in a relation of freedom and equality to persons on whom one depends for one's status.

The forward-looking question does not take the political unit for given but asks which division of units best secures the status of equal freedom. From the perspective of the principle of affected status, we do not ask whether our interests are affected in order to determine who should be included. Rather, we ask whether common political institutions are required in order to secure our equal freedom. If persons live so close together that their different purposes are likely to clash, that is, if they are mutually dependent on each other for their freedom, then they ought to unite under a common will and a shared public legal order; they ought to constitute a common demos.

\section{Against and for expanding the demos}

In light of earlier discussions of the nature of democracy and the all-affected principle, we have developed our own version of the latter, the all-affected status principle, and we have indicated the backward- and forward-looking implications of this principle. In general, the latter point to the expansion of the demos beyond any given nation state and concretely against both unilateral and multilateral withdrawal from the EU - as we argue in the next section.

However, other democratic reasons have been given more specifically in favour of delimiting the demos, even against the acknowledged normative force of the all-affected principle. They centre on the necessary preconditions of realizing democratic rule, the quality of the democratic processes and the intrinsic value of national self-determination. In this section, we first briefly list the arguments in favour of delimiting the demos in a certain way, predominantly along the boundaries of pre-existing nations and/or states. We then discuss whether these 'democratic reasons' for delimiting the demos are weighty reasons and whether they reflect legitimate concerns in the case of the EU and in relation to any realistic realization of our all-affected status principle.

Miller (2009) has argued that even if the all-affected principle is part of the theory of democracy, there are other central tenets of democratic thought relating to the properties of a 'good demos' that ought to be included in thinking about the boundaries of the demos. He points out that even 'liberal democrats', that is, the democrats most minded on including as 
many affected interests as possible, find it necessary to delimit the demos. Discussing Mill's argument for representative government, Miller claims that a certain social unity, a shared language and political culture is necessary for holding government responsible and ensuring against its encroachment on the liberties of citizens (Miller 2009, 211-12). Miller's liberal nationalist argument points to the instrumental value of national identity and a common public culture for a well-functioning democracy, and he rejects global democracy because of the likely lacking willingness based on shared interests and beliefs of all involved to subject themselves to a common democratic authority (Miller 1995, 2010, 145). The importance of politics in the vernacular and a shared political culture for democracy has also led writers such as Dahl (1999) and Kymlicka (1999) to argue against international democracy. A certain responsive attitude towards co-citizens' claims arising out of a shared identity and political culture is necessary, and only political debate in the common native tongue is genuine and allows everybody to follow and participate in it. Dahl (1999) has also pointed to the inability of 'ordinary citizens' to relate to complex 'foreign policy issues' and make informed decisions. Adopting formal democratic institutions at the international level would thus amount to a form of ideological masquerade, giving elites free rein in the name of a purely formal democracy.

Song (2012) has argued that democracy is most appropriately realized in existing states since states are able to ensure the fundamental democratic principle of equality by distributing equal (political, civil, and socio-economic) rights through laws and welfare institutions and by instantiating the political institutional infrastructure that can generate trust and solidarity, through the reiterated experience of citizens making decisions together and the ensuing (feeling of) transparency and political efficacy among citizens. Basing democracy (solely) on the all-affected or the all-subjected principle with the resulting perennial shift in demos according to who is affected or subjected by any given decision would undermine this infrastructure and, hence, the preconditions for democratic equality (Song 2012, 57-58). Similarly, Christiano (2012) has argued that the distribution of equal democratic rights, essential for realizing equality in a public recognizable manner, only makes sense inside the framework of existing states, where all citizens have approximately equal stakes in 'a common world' and not 'outside' of states, where this is not the case. States are historically contingent but have become morally relevant over time in the constitution of a common world and equal stakes, and by their capacity to realize equality publicly through equal rights.

Besides the instrumental value that nations and states have for democracy, nations (and states?) provide individuals with an intrinsically valuable (self-)identity, which places them securely in the world and give 
them an answer to the crucial question of 'who they are'. Losing this identity can be painful. For this reason and for the instrumental benefits of shared nationhood, Miller (1995) argues for the right to national self-determination and, hence, for delimiting the demos by the boundaries of the nation. And to be sure, many sceptics of international or supranational political authority fear that it might put national identity and valued diversity at risk.

National self-determination can also be seen as intrinsically valuable because it facilitates the members of communities to be engaged in the present and future of their community through collective self-government and the shaping of the conditions of their own existence. Collective selfdetermination gives individual citizens more autonomy or adds a qualitatively different dimension to their autonomy above and beyond the autonomy they exercise in their private lives. When denied collective selfdetermination, people are disrespected because it is presumed that they are not able to govern themselves (Moore 2009, 392). Arguments based on the principles of self-determination (Philpott 1995) and equal respect for each individual's authority to make decisions regarding their own lives and the collective life of their society (Copp 1997) have been used in favour of secession, in particular, where units are relatively independent of each other and in situations in which the members of (prospectively independent) subunits are (permanent) minorities, which have to 'constantly combat or be drowned in the dissonance of foreign ways' (Philpott 1995, 360).

Finally, national self-determination can be seen as a protection against centralization and the institution of a powerful political centre that threatens to level or eradicate valued diversity. The Kantian apprehension of the soulless despotism that world government would entail and his praise for the friendly competition between diverse nations is the classical example of this line of reasoning (Kant 1996b). The soulless despotism would suppress freedom, including democratic freedom. National self-determination thus has an instrumental value in this regard.

\section{Replies}

The arguments for delimiting the demos along the boundaries of existing nations or states could all be seen as democratic reasons for not giving too much weight to the all-affected principle in deciding which democratic reasons can be given for and against allowing (unilateral) withdrawal from the EU. (One exception may be the argument about the intrinsic value of national identity; this is not per se an argument about democracy.) In the following, we address these democratic reasons in turn. Before we do, two preliminary remarks. 
First, nations have conventionally been seen as units of self-government for one central reason, namely, that the interests of the members of individual nations are more closely interconnected than the interests of people belonging to different nations (Goodin 2007, 48). To the extent that this is not (or no longer) the case, the reason for delimiting the demos in this way is not obvious. This is part of the argument for demarcating the demos according to who may be affected by particular decisions.

Second, the argument against withdrawal from the EU does not necessarily imply an argument for the eradication of existing national state structures and institutions. The latter can remain largely intact for countries staying in the EU. This also means that many issues will still be determined by member states on their own, enabling them to shape their own conditions and pursuing collective projects through practices of self-government. This is, however, different from exercising full sovereignty. Our argument is not an argument for strong centralization. Many decisions are decomposable (Goodin 2007, 65). The EU is generally built by integrating existing units into its structure, not by making new units. A number of the concerns about the quality of democratic life can thus be met by emphasizing the continued decentralized structure of the EU. With these two preliminaries in place, we address each of the reasons for delimiting the demos along the lines of existing nations and states.

Regarding the question about trust and ensuing solidarity as preconditions for democracy, something that is usually seen as growing out of a shared identity, it should be questioned whether trust in one's co-nationals is a particularly democratic virtue. This seems to require that national identity can be used as a reliable proxy for the behaviour of specific people, in particular, political elites, in taking an interest in others' interest (McBride 2010,171-73). This is, however, doubtful, and nationality-based trust paves the way for elites to manipulate and dominate co-nationals by playing the nationalist card. A better cue may therefore be the presence of institutional mechanisms that 'give us a relatively clear sense of the incentive structure within which any cooperative action takes place' (McBride 2010,174). Indeed, transparent and reliable institutions may be a better or just as good a source for building trust and solidarity as a shared identity (Abizadeh 2002). Also, multi-language democracies (Switzerland, Canada) work reasonably well.

Second, identities and political cultures are to a large extent the result of (political) institutions and should therefore not be seen as their preconditions. If institutions of the right quality are given time to work, identities and political culture(s) are likely to grow from them too (Kumlin and Rothstein 2005). Concretely, the EU does not entail the dissolution of national identities, political cultures, or institutional structures but only 
adds yet another layer. To the extent that these institutions contribute to democracy at the national level, expanding 'the demos' with regard to common and boundary crossing issues at the European level does not undermine democracy. Indeed, we suggest that it enhances democracy because excluding 'democratic institutions' at the international or regional level means leaving an increasing number of issues to executives and diplomats. The ability of 'ordinary citizens' to generate informed opinions about so-called foreign policy issues to a large extent depends on whether these issues are a part of public debate and object of regular political contestation between different parties (Føllesdal and Hix 2006; Føllesdal 2012).

To the extent that national state structures are not dissolved and that the all-affected status principle is interpreted in terms of adding layers to the existing political institutions in order to deal with common and boundary crossing issues, the state infrastructure that supposedly ensures the preconditions for realizing equality is not disrupted. In addition, the EU structure provides a stable framework for making repeated decisions among roughly the same number of citizens, which would eventually lead to the same kind of trust and solidarity generation that state structures bring. According to Song, trust and solidarity are to a large extent a result of time. As regards the instantiation of equality in terms of the distribution of equal rights, the question is how rigidly this should be understood. In the $\mathrm{EU}$, the equal fundamental rights of individuals and citizens have been established as a principle even if the structure still allows for, for instance, differentiation in certain rights (voting rights in national elections) and ascribes more weight to the votes of some (citizens of smaller states) than others (citizens of larger states). A rigid interpretation of equality of rights would disqualify most known political structures with any degree of decentralization, including federal ones. As regards Christiano's claim about equal stakes inside and outside of states, some people may have more 'equal stakes' with persons across borders than inside them. Further, people may not be aware what their stakes in cross-border relations are since the effects of international regimes (e.g. free trade regimes) are subtle and require politicization for people to realize what their stakes in them are (Chimni 2012; Føllesdal 2012; K. McDonald 2012).

Regarding the intrinsic value of national identity, EU's structure does not threaten national identity unless it is tied to sovereignty and based on an antagonistic relation to other nations. The true value of knowing 'who you are' does not need to come from identities constructed in such a manner, nor does national identity have to be so constructed (Abizadeh 2005). Several authors have demonstrated how a European identity would be compatible with a national one, for example, as understood in terms of 
concentric circles or as consisting in its specific sensitivity towards diversity (Camia 2010). More importantly, however, democracy 'across borders' should not be conceptualized in terms of the creation of a new demos in a substantial manner. The institutional set-up of the EU, EU rights, and EU citizenship allow people to 'govern together but not as one' to use a formula from an advocate of EU as demoi-cracy (Nicolaidis 2013). The EU connects citizens and 'peoples' with each other institutionally and across borders.

As concerns the intrinsic value of national self-determination, it should be noted that the EU structure does not eliminate all self-determination. It is therefore still possible to pursue common self-governing projects. However, if the conditions of citizens are determined by factors beyond the control of national (state) institutions, the value of national self-determination is seriously reduced (Held 1995). Moreover, a central question is whether the value of 'self-determination' and/or the preference that members have for self-determination regardless of its effectiveness should trump the interests of those 'outside' the self-determining community whose status is affected by the community's decisions. We think it should not. First, under current conditions, sovereign national self-determination is illusory and hence not a cogent idea. Second, it implies that the 'self-rule' of some would undermine the right to self-rule of others. To paraphrase Moore, it would imply the disrespect of those others as not worthy of participating in the decisions that govern them. Thus, our point is not that supranational democratic equality as a matter of principle is more important than national self-determination, but that the value of the latter has been diminished by factual circumstances of interdependence.

Finally, in relation to the fear of centralization and soulless despotism, the all-affected status principle does not necessarily imply a high degree of centralization. Political structures can be built that ensure against centralization, as is the case in the EU, where representatives from the units are strongly represented at the central level (in the European Council and the Council of Ministers) and where subsidiarity procedures include national parliaments. Nor is the argument that states or nations should be forced to join the EU. Forcing states or people to join the EU would as a minimum presuppose an already existing common democratic authority. However, the principle does imply that states whose citizens are implicated in relations of interdependence which make foreigners vulnerable in terms of their status as free and equal citizens ought to participate in democratically structured international cooperation. But this is a moral duty rather than a legally enforceable one. There is a difference between what would be the right thing to do and what people and states can be forced to do.

Taken together, then, the arguments for delimiting the demos along existing nations and states and for privileging national self-determination 
understood as national sovereignty do not overrule the rights of outsiders to participate in the decisions that - across borders - affect their status. This conclusion is strengthened by the fact that collective identity loss, the loss of the intrinsic good of national self-determination and a diminished quality of democratic life are not necessary consequences of any reasonable realization of the all-affected status principle. They can be realized at the same time as the all-affected status principle since they do not require absolute national sovereignty. The latter is in any case an unrealistic idea under current conditions. With this conclusion in place, we are now finally able to demonstrate that withdrawal from the EU is not democratic.

\section{Affected status and withdrawal}

We divide our discussion into backward-looking and forward-looking considerations. The backward-looking considerations take the political units for given and bear on whether democratic reasons, on balance, count in favour of leaving the decision of withdrawal to (a) the demos of a member state (unilateral withdrawal) or (b) to the demos of the entire EU (multilaterally agreed withdrawal). The forward-looking considerations do not take the units for given and bear on what substantial decisions ought to be made (whoever makes it), that is, it informs whether withdrawal furthers or hinders the cause of democracy.

\section{Backward-looking considerations}

Looking backward, the normative, democratic consideration is whether you are included in the decision making of the political unit that determines your status as a subject and a ruler. The democratic principle, as we have interpreted it, entails that in so far as a political unit determines your politicallegal status, you ought to be included, as an equal, in the decision-making processes of that unit. With regard to our case, the status of EU citizens is determined by more than one unit, most importantly, the EU and the member state. Thus, even though the backward-looking consideration must take the political unit for given, the problem in the present case is which unit should be taken for given. Those who think unilateral withdrawal is (the most) democratic might think that the member state can be taken for given and that those who are subjected to the laws of the member state, and only those, are entitled to determine the fate of the member state. There are two problems with this argument: first, the status of the citizens of the member state is not only determined by that member state but also by the EU. Second, not only the status of citizens of the member state, who are included in a unilateral decision to withdraw, but also the status of other EU citizens is changed by withdrawal. Let us substantiate these two claims. 
Regarding the first claim, what are the implications of the fact that the status of the citizens of the potentially withdrawing state is determined not only by their member state but also by the EU? The demos of a member state deciding to withdraw, using their country's democratic procedures such as the British people have done in their exit decision (cf. Eeckhout and Frantziou 2016) - decide to get rid of their status as EU citizens. Thereby, they use their status as citizens of one political unit, in this case their status of citizens of the United Kingdom, to change their status as citizens of another political unit, the EU. This is normatively significant if we understand the status that one has not as an individual possession, or a benefit one enjoys, but rather as a relation in which one stands to other people. The status of being an EU citizen is one British citizens have in relation to other EU citizens, not only one they have in relation to one another as British citizens. By using democratic procedures that are democratic in relation to the British demos, they change the material status of the members of a different demos (the citizens of the EU) without including the latter in the decision-making process. This is a democratic problem not only for non-British citizens, but also for British citizens themselves insofar as the latter have an additional status that was not respected in the decisionmaking process. And insofar as a democratic decision, in practice, is always only a decision by part of the demos, the majority, members of the minority have had their status changed in a demos where they might have been part of the majority. This is likely to be the case among the large minority of $48 \%$ who voted for the United Kingdom to remain in the EU.

Regarding the second claim, the democratic deficit of unilateral withdrawal is even clearer in relation to other EU citizens not part of the demos of the withdrawing state. The material status of these other citizens has changed in relation to the withdrawing state and its citizens without their opportunity to have a democratic say. When a member state like the United Kingdom decides to withdraw from the Union, it is likely seriously to affect and limit the rights that currently exist across borders in the EU and, thus, change the legal status and the status as rulers of all EU citizens, not merely the status of members of the withdrawing state, in this case the United Kingdom. Setting aside the discussion about the probable content of agreements between the withdrawing state and the remaining EU, for example, whether the United Kingdom ends up with a soft or a hard form of Brexit, it would mean that EU citizens outside the withdrawing country would lose significant rights in that country as private individuals. As citizens, they would lose the ability to exert influence on political issues pertaining to the political system of the withdrawn state. The point is not merely that citizens from other member states will lose the ability to do certain things they would otherwise be able to do in the withdrawn state 
(which might also happen if another foreign country in which one lives changes its laws) but, rather, that the legal status as rights bearers and co-rulers created by common institutions is violated.

Withdrawal implies that decisions, which are now under the authority of the EU, and which EU citizens can therefore influence because of the political rights entailed in their EU citizenship, will be removed from the EU as the competence conferred upon the EU reverts to the withdrawing state. Indeed, the argument for Brexit was in part that the United Kingdom should 'take back control'. However, this means that the remaining EU citizens will lose influence on matters that may affect their status as individual rights holders and co-rulers. It also means that (what would presumably be) a minority of (EU) citizens of the withdrawing state (the $48 \%$ minority in the British case) will lose their ability to influence EU decisions against their will. It will cancel their democratic rights as EU citizens. Having moved to the withdrawing country, EU citizens from other countries would be in an uncertain legal situation since their rights are ensured by European legislation and fundamental principles, especially non-discrimination on the basis of nationality. The post Brexit referendum discussion about the rights of other Union citizens' future rights in the United Kingdom illustrates this point (Garner 2016).

In sum, for EU citizens who are not national citizens of a withdrawing state like the United Kingdom, withdrawal is likely to have significant effects in terms of their legal status as bearers of civil and political rights across borders. EU law and fundamental principles in a very important manner secure 'the rights of others' in relation to individual member states. What is more, EU law and principles also ensure significant rights to nationals of a potential withdrawing state, both as private individuals and citizens, that is, rights to do different things in other EU countries than their own and to exert influence on political matters that affect their status. Withdrawal would have direct negative effects on the rights that people possess as private individuals, but it would also deprive (other) people of the democratic right to influence decisions that affect their status. Hence, the act of unilateral withdrawal by a member state such as the United Kingdom violates the principle that everyone whose status is determined by a decision ought to be included in making it. If this is a fundamental democratic principle, unilateral withdrawal contravenes a fundamental democratic principle.

Now, some might think it unreasonable that no one could ever change a relationship unilaterally, just because it changes the status of the other people involved. Marriage could be a case in point. Here we would normally think that it should be voluntary for people to leave the relationship even if the other party resists. And indeed, article 50 of the TEU has 
been called the EU's divorce clause. However, there is a difference of kind between private (contractual) relationships and political relationships. The former regards changing the legal status of people within the framework of the law. The latter regards establishing and changing the framework of the public (and private) law and is thereby fundamental to the status of people in their public relationship as free and equal citizens.

\section{Forward-looking considerations}

The fundamental democratic principle of protecting a status of equal freedom can contribute also to our forward-looking considerations. These considerations concern our aspirations for furthering the cause of democracy in the future. Regarding the demos or boundary question, we do not merely ask if the decision made by a particular political unit included everyone subject to the decision of that unit. We ask which decisions ought to be made with regard to constituting the demos in order to further the ideal that everyone achieves or upholds the status of standing in a relation of equal freedom to others who may threaten that status. In respect to our present case, we ask whether withdrawal of a member state such as the United Kingdom furthers or limits the security of the status of equal freedom of all EU citizens.

From the forward-looking perspective, the democratic problem with withdrawal from the EU is that all EU citizens' ability to democratically influence future decisions that affect their status is diminished. The EU has contributed to and is part of a process of supranationalization that makes us all more interdependent and thus increases the need for being protected in one's status as not being subject to the arbitrary will of another. When a member state like the United Kingdom withdraws from the EU (unilaterally or not), the status of all EU citizens will continue to be seriously affected by and dependent on both EU decisions and decisions made in the withdrawn state. But the citizens whose equal freedom is in question will have lost some of their ability or power to influence decisions that affect their status. Thus, the democratic ambition to approximate an identity between the status of being a rights bearer and being a ruler has been curtailed and not promoted.

It is important to note that this forward-looking argument does not rely on the premise that (existing) democratic procedures have been violated but rather on the premise that a fundamental principle has been violated, a principle that informs both which procedures count as democratic and which people ought to be included in which decisions - or which political units ought to be defended or established. Thus, the forward-looking argument concerns what ought to be decided regarding withdrawal, whoever decides it. And the argument is that withdrawal cannot be 
defended on democratic grounds, because it entails (it has the future consequence of) moving us further away from (rather than closer to) the democratic ideal that the people whose status is mutually interdependent ought to make decisions together. They ought to make decisions together in order to secure their freedom from being subject to alien decisions, that is, to be guarded against decisions regarding their status made by others without including them.

\section{Objections}

It may be objected to our argument that by way of the Lisbon Treaty, a large segment of the EU citizens potentially affected by withdrawal from the EU have already through a democratic procedure (i.e. treaty ratification) granted each other the right as citizens of individual member states to withdraw. As noted, this could be seen as recognition of the continued right to national self-determination, and one could argue that the status as rights holder and ruler that the EU affords EU citizens is a conditional status. This objection is met by the conclusions from the forward-looking considerations. Withdrawal is detrimental to future democracy and cannot be considered democratic regardless of the procedure. Not every democratically made decision is a democratic decision.

A second objection to our argument is that people do not value the rights they have as EU citizens very highly and significantly less than their national rights and that it is odd to defend rights that people, like the UK referendum majority, do not really value. The withdrawal clause may be an indication of this as is the relatively low utilization of free movement rights [in 2009, only 2.4 of EU citizens lived in other EU countries than their own (Vasileva 2010)] and European political rights (voter turnout was $43.1 \%$ in the 2014 EP election). However, reverting to national sovereignty and national political rights would only entail a diminished ability to influence decisions that affect you and, hence, also entail diminished political autonomy. Nonetheless, it might be that some or even many EU citizens do not value their ability to influence something that affects their status. They cannot, however, defend this position on democratic grounds, that is, with reference to the principle that one should have a say in what affects one's status. To be more precise, a people can, without violating democratic decisionmaking procedures, make decisions that are detrimental to democracy, but they cannot defend the latter with reference to democratic principles.

However, a third objection could be that the EU's democratic deficit makes it legitimate for a state to withdraw because the democratic deficit triggers a remedial right to secession as some theories of secession suggest (Buchanan 2004). The democratic deficit would represent a 
violation of fundamental democratic rights. Part of the UK's leave campaign was based on a rejection of Brussels' bureaucrats and red tape. This raises two questions, namely how large the democratic deficit is and what would eventually be the most appropriate response to this deficit: to stay or to go. The size and nature of the EU democratic deficit has been widely debated. One position says that there is really no deficit by conventional democratic standards (Moravcsik 2002), while others think that by those standards, the EU still suffers from a lack of institutionally structured processes that give confidence that the true preferences of citizens have been tracked (Føllesdal and Hix 2006). According to Føllesdal and Hix (2006), this requires an open and explicit political contestation over competing political programmes that can, among other things, elucidate the important redistributive consequences of EU policies. However, Hix and Føllesdal also find that democratic shortcomings are due mainly to the failure of political actors to use the institutional structures and procedures already in place to create proper political competition in their appeal to voters (Føllesdal and Hix 2006, 557). But even if there were a large remaining deficit, we think that the appropriate democratic first response would be to improve on fundamental democratic rights in the EU and conditions of exercising them rather than to withdraw (Sunstein 1990).

A final objection would come from proponents of EU democracy as a demoi-cracy. They seek to place the EU between 'international' models of European democracy in which EU's legitimacy derives indirectly from national democratic institutions on the one hand and a federal model of democracy based on the idea of a European demos represented by the European Parliament on the other. Demoicracy is based on the idea that the demoi of Europe should 'govern together and not as one' (Nicolaidis 2013, 351). Demoicracy is a complex model of democracy and we cannot do full justice to it here. A key concern is with ensuring against domination between states or 'statespeoples' (Cheneval 2011; Cheneval and Schimmelfennig 2013; Nicolaidis 2013; Cheneval, Lavenex, and Schimmelfennig 2015). And the purpose of creating a multilateral democratic order such as the EU would in large part be to avoid domination between states. Crucial for the present argument, demoicracy is based on the continued sovereignty of the pouvoir constituants of the EU member states. This sovereignty implies that member states (using proper constitutional procedures) should be free to decide to enter and to leave the EU and that they each possess a veto with regard to any further development of the basic rules of the EU through treaty revisions (Cheneval 2011, 133-40; Cheneval, Lavenex, and Schimmelfennig 2015, 4). All this in order to ensure against domination, including domination by the centre of the individual member states. 
We have already argued that the democratic value of sovereign national self-determination is undercut by the fact of interdependence and cannot override the right of outsiders to participate in decisions that affect their status. And further, that the remaining value of national identity and self-determination can be realized within a decentralized EU structure that largely maintain existing national democratic institutions. We have also argued that unilateral withdrawal changes the status of a whole number of European citizens without giving them a say in the decision. As such withdrawal can itself be a case of domination. Demoicrats might claim that the right to withdraw protects (smaller) individual member states against domination from the centre. However, as argued above, the first response to an undemocratic centre would be to aim for its democratization. Furthermore, demoicrats need to show that using the right to exit is necessary and not disproportionate to the aim of non-domination they pursue. Our argument is not directed at the right to withdrawal but concerns the democratic credentials of its use. Regarding the latter, we do not deny that there might be conditions under which the right could be used as a remedy against domination, but only that normally this is not the case. Other means such as properly designed power sharing, checks and balances, and decentralization would be sufficient, also considering the threat of domination that results from (anarchical) international order based on sovereignty. In relation to the key formula of demoicracy, 'governing together, but not as one', it should be remembered that people cannot govern (well) together if one party leaves (or threatens to leave) (Sunstein 1990).

\section{Conclusion}

We have argued that unilateral withdrawal by individual member states such as it has been decided by the United Kingdom, using its right introduced by the Lisbon Treaty is undemocratic. The fundamental democratic principle implies that people should rule themselves and make decisions that enable them to continue to rule themselves in the future. Unilateral decisions to withdraw from the EU do not live up to this principle. First, they exclude people from participating in a decision that affects their status as rights holders and corulers, and hence, they do not rule themselves. Second, it diminishes the ability of citizens whose status is vulnerable to each other's actions to rule themselves together in the future though common institutions at the European level. They move away from rather than towards the ideal of democratic rule. This also means that even a multilaterally agreed decision to allow an individual nation to withdraw from the EU is undemocratic because of its detrimental consequences for future democracy. 


\section{Acknowledgments}

We would like to thank Mads Dagnis Jensen, Per Mouritsen, Kasper LippertRasmussen, Søren Flinch Midtgaard, Morten Brænder, Gustaf Arrhenius and the reviewers and editors of International Theory for valuable comments and suggestions. The authors remain responsible for the article's shortcomings.

\section{References}

Abizadeh, Arash 2002. "Does Liberal Democracy Presuppose a Cultural Nation? Four Arguments." American Political Science Review 96(3):495-509.

Abizadeh, Arash 2005. "Does Collective Identity Presuppose an Other? On the Alleged Incoherence of Global Solidarity." American Political Science Review 99(1):45-60.

Abizadeh, Arash 2008. "Democratic Theory and Border Coercion. No Right to Unilaterally Control Your Own Borders." Political Theory 36(1):37-65.

Arrhenius, Gustaf 2012. “The Boundary Problem in Democratic Theory." Manuscript, Stockholm: Stockholm University.

Benhabib, Seyla 2004. The Rights of Others: Aliens, Residents, and Citizens. Cambridge: Cambridge University Press.

Bohman, James 2007. Democracy Across Borders. Cambridge, MA: MIT Press.

Brettschneider, Corey 2007. Democratic Rights: The Substance of Self-Government. Princeton, NJ: Princeton University Press.

Buchanan, Allan 2004. Justice Legitimacy, and Self-Determination: Moral Foundations of International Law. New York: Oxford University Press.

Buchanan, Allan, and Robert O. Keohane. 2006. "The Legitimacy of Global Governance Institutions." Ethics \& International Affairs 20(4):405-37.

Camia, Valeria 2010. "Normative Discussions on European Identity: A Puzzle for Social Science?" Perspectives on European Politics and Society 11(1):109-18.

Cheneval, Francis 2011. The Government of the Peoples: On the Idea and Principles of Multilateral Democracy. New York: Palgrave Macmillan.

Cheneval, Francis, and Frank Schimmelfennig. 2013. "The Case for Demoicracy in the European Union." JCMS 51(2):334-50.

Cheneval, Francis, Sandra Lavenex, and Frank Schimmelfennig. 2015. "Demoi-Cracy in the European Union: Principles, Institutions, Policies." Journal of European Public Policy 22(1):1-18.

Chimni, B. S. 2012. "Global Capitalism and Global Democracy: Subverting the Other?." In Global Democracy: Normative and Empirical Perspectives, edited by Daniele Archibugi, Mathias Koenig-Archibugi, and Raffaele Marchetti, 233-53. Cambridge: Cambridge University Press.

Christiano, Thomas 2012. "Is Democratic Legitimacy Possible for International Institutions?." In Global Democracy: Normative and Empirical Perspectives, edited by Daniele Archibugi, Mathias Koenig-Archibugi, and Raffaele Marchetti, 69-95. Cambridge: Cambridge University Press.

Connolly, William E. 1993. The Terms of Political Discourse, 3rd ed Princeton, NJ: Princeton University Press.

Copp, David 1997. "Democracy and Communal Self-Determination." In The Morality of Nationalism 277-300, edited by Jeff McMahan, and Robert McKim. Oxford: Oxford University Press. 
Dahl, Robert A. 1989. Democracy and its Critics. New Haven, CT: Yale University Press.

Dahl, Robert A. 1990. After the Revolution? Authority in a Good Society, Revised ed New Haven, CT: Yale University Press.

Dahl, Robert A. 1999. "Can International Organisations be Democratic? A Skeptic's View." In Democracy's Edges, edited by Ian Shapiro, and Casiano Hacker-Cordón, 19-36. Cambridge: Cambridge University Press.

De Burca, Gráinne 2011. "The Evolution of EU Human Rights." In The Evolution of EU Law, edited by Paul Craig, and Gráinne De Burca, 464-97. Oxford: Oxford University Press.

Eeckhout, Piet, and Eleni Frantziou. 2016. "Brexit and Article 50 TEU: A Constitutional Reading." UCL European Institute, Working Paper, London, December. Accessed August 22, 2017. https://www.ucl.ac.uk/european-institute/brexit-article-50.pdf.

European Union (EU). 2010. Consolidated Treaties - Charter of Rights. Luxembourg: Publications Office of the European Union.

Føllesdal, Andreas 2012. "Cosmopolitan Democracy: Neither a Category Mistake or Categorical Imperative." In Global Democracy: Normative and Empirical Perspectives, edited by Daniele Archibugi, Mathias Koenig-Archibugi, and Raffaele Marchetti, 96-114. Cambridge: Cambridge University Press.

Føllesdal, Andreas, and Simon Hix. 2006. "Why There is a Democratic Deficit in the EU: A Response to Majone and Moravcsik." JCMS 44(3):533-62.

Forst, Rainer 2007. "Cosmopolitan Republicanism or Republican Cosmopolitanism? Comment on James Bohman." In How to Reconstitute Democracy in Europe?, edited by O. Eriksen, 91-94. Oslo: ARENA, ARENA Report No. 8/07.

Garner, Oliver 2016. "After Brexit: Protecting European Citizens and Citizenship from Fragmentation." EUI Department of Law Working Paper No. 2016/22. Accessed August 22, 2017. https://ssrn.com/abstract=2871404.

Goodin, Robert 2007. "Enfranchising all Affected Interests, and its Alternatives.” Philosophy and Public Affairs 35(1):40-68.

Gould, Carol C. 2004. Globalizing Democracy and Human Rights. Cambridge: Cambridge University Press.

Gould, Carol C. 2012. "Regional Versus Global Democracy: Advantages and Limitations." In Global Democracy: Normative and Empirical Perspectives, edited by Daniele Archibugi, Mathias Koenig-Archibugi, and Raffaele Marchetti, 115-31. Cambridge: Cambridge University Press.

Held, David 1995. Democracy and the Global Order. Cambridge: Polity Press.

Held, David 2010. "Reframing Global Governance: Apocalypse Soon or Reform." In The Cosmopolitanism Reader, edited by Garrett W. Brown, and David Held, 293-311. Cambridge: Polity Press.

Hofmeister, Hannes 2010. “'Should I Stay or Should I Go?' - A Critical Analysis of the Right to Withdraw From the EU.” European Law Journal 16(5):589-603.

Holberg, Jacob Schall 2010. "The Treaty of Lisbon - Towards an Ever Closer Union, With a Formal Withdrawal Procedure." The Columbia Journal of European Law Online 17:10-16.

Kant, Immanuel 1996a. "The Metaphysics of Morals.” In Practical Philosophy, Translated and edited by Mary J. Gregor, 353-603. New York: Cambridge University Press.

Kant, Immanuel 1996b. “Toward Perpetual Peace.” In Practical Philosophy, Translated and edited by Mary J. Gregor, 311-51. New York: Cambridge University Press.

Kumlin, Staffan, and Bo Rothstein. 2005. "Making and Breaking Social Capital - The Impact of Welfare Institutions.” Comparative Political Studies 38(4):339-65. 
Kymlicka, Will 1999. "Citizenship in the Era of Globalization: A Commentary on Held." In Democracy's Edges, edited by Ian Shapiro, and Casiano Hacker-Cordón, 112-26. Cambridge: Cambridge University Press.

López-Guerra, Claudio 2005. “Should Expatriates Vote?” Journal of Political Philosophy 13(2): 216-234.

Marchetti, Raffaele 2012. "Models of Global Democracy: In Defence of Cosmos-Federalism.” In Global Democracy: Normative and Empirical Perspectives, edited by Daniele Archibugi, Mathias Koenig-Archibugi, and Raffaele Marchetti, 22-46. Cambridge: Cambridge University Press.

McBride, Cillian 2010. "Postnationalist Democratization: Rethinking Nationality, Trust, and Accountability.” In After the Nation, edited by Keith Breen, and Shane O’Neill, 161-76. Basingstoke: Palgrave Macmillan.

McDonald, Kate 2012. "Global Democracy for a Partially Joined-Up World: Toward a Multilevel System of Public Power and Democratic Governance?.” In Global Democracy: Normative and Empirical Perspectives, edited by Daniele Archibugi, Mathias Koenig-Archibugi, and Raffaele Marchetti, 183-209. Cambridge: Cambridge University Press.

McDonald, Terry 2012. "Citizens or Stakeholders Exclusion, Equality and Legitimacy in Global Stakeholder Democracy.” In Global Democracy: Normative and Empirical Perspectives, edited by Daniele Archibugi, Mathias Koenig-Archibugi, and Raffaele Marchetti, 47-68. Cambridge: Cambridge University Press.

Mill, John Stuart 1991. "Considerations on Representative Government." In On Liberty and Other Writings, edited by J. Gray. New York: Oxford University Press.

Miller, David 1995. On Nationality. Oxford: Oxford University Press.

Miller, David 2009. "Democracy's Domain.” Philosophy \& Public Affairs 37(3):201-28.

Miller, David 2010. “Against Global Democracy.” In After The Nation, edited by Keith Breen, and Shane O’Neill, 141-60. Basingstoke: Palgrave Macmillan.

Moore, Margaret 2009. "Is Patriotism an Associative Duty?" The Journal of Ethics 13(4): 383-399.

Moravcsik, Andrew 2002. "In Defence of the 'Democratic Deficit': Reassessing Legitimacy in the European Union." JCMS 40(4):603-24.

Näsström, Sofia 2011. “The Challenge of the All-Affected Principle.” Political Studies 59(1): 116-134.

Nicolaidis, Kalypso 2013. "European Demoicracy and its Crisis.” JCMS 51(2):351-69.

Olsen, Tore Vincents 2011. "The Political Constitution of the EU Citizen Rights Regime." Journal of European Public Policy 18(1):35-52.

Pettit, Philip 1997. Republicanism: A Theory of Freedom and Government. Oxford: Oxford University Press.

Pettit, Philip 2010. “A Republican Law of Peoples.” European Journal of Political Theory 9(1): $70-94$.

Philpott, Daniel 1995. "In Defense of Self-Determination.” Ethics 105(2):352-85.

Rostbøll, Christian F. 2016. "Kant, Freedom as Independence, and Democracy.” The Journal of Politics 78(3):792-805.

Saunders, Ben 2011. "Defining the Demos." Politics, Philosophy \& Economics 11(3): 280-301.

Schumpeter, Joseph A. 1975. Capitalism, Socialism and Democracy. New York: Harper Torchbooks.

Song, Sarah 2012. "The Boundary Problem in Democratic Theory: Why the Demos Should be Bounded by the State." International Theory 4(1):39-68. 
Why withdrawal from the EU is undemocratic 465

Sunstein, Cass 1990. "Constitutionalism and Secession.” The University of Chicago Law Review 58(2):633-70.

Vasileva, Katya 2010. "Foreigners in the EU are Diverse and Largely Younger than the Nationals of the EU Member States." Statistics in Focus 45/2010, Eurostat, Luxembourg. Accessed August 22, 2017. http://ec.europa.eu/eurostat/documents/3433488/5565568/KS-SF-10045-EN.PDF/389f77c3-8b09-4b4c-8ddd-a2d77b1802b6.

Whelan, Frederick G. 1983. "Prologue: Democratic Theory and the Boundary Problem." In Liberal Democracy - Nomos XXV, edited by J. Roland Pennock, and John W. Chapman, 13-48. New York: New York University Press. 